\title{
Reconstruction of Criminal Conspiracy in Indonesia's Corruption Crime Law Based on Progressive Law
}

\author{
Aris Suliyono $^{1 *}$, Gunarto ${ }^{2}$, Sri Endah Wahyuningsih ${ }^{3}$, Ngadino $^{4}$ \\ ${ }^{1}$ Doctorate Student of Faculty of Law Sultan Agung Islamic University Semarang, Indonesia \\ ${ }^{2-4}$ Faculty of Law Sultan Agung Islamic University Semarang, Indonesia
}

DOI: $\underline{10.36348 / \text { sijlcj.2020.v03i11.005 }}$

| Received: 28.10.2020 | Accepted: 09.11.2020 | Published: 11.11 .2020

*Corresponding author: Aris Suliyono

Abstract

The act of conspiracy in the criminal act of corruption in Indonesia is very difficult to prove because the standard definition and elements of criminal conspiracy in cases of corruption are different from the definition of Conspiracy in other crimes. This situation is getting more complicated because the elements and definitions of the standard of conspiracy in corruption cases are not clearly regulated. This encourages the author to conduct a study on the subject matter of what are the weaknesses of the law in the case of criminal conspiracy in the criminal act of corruption to then carry out the reconstruction of the Conspiracy in criminal acts of corruption based on progressive law. The paradigm in this research is constructivism and the type of research used is descriptive-analytical. Based on the research conducted, it is found that the implementation of law enforcement in cases of conspiracy related to corruption in Indonesia is not yet fair, this is due to the unclear elements in the criminal Conspiracy in cases of corruption. The weaknesses that result in this are weaknesses in the form of overlapping rules, law enforcement which only prioritizes proof in the form of real losses and ignores the meetings of mind, the influence of power, and politics. So it is necessary to reconstruct Article 2 by adding the phrase "can" and Article 15 of Law Number 31 of the Year 1999 Jo. Law Number 20 Year 2001 Concerning the Eradication of Corruption Crime.

Keywords: Reconstruction, Conspiracy, Corruption, Progressive Law.

Copyright (C) 2020 The Author(s): This is an open-access article distributed under the terms of the Creative Commons Attribution 4.0 International License (CC BY-NC 4.0) which permits unrestricted use, distribution, and reproduction in any medium for non-commercial use provided the original author and source are credited.

\section{INTRODUCTION}

Based on Article 110 paragraph (1) of the Criminal Code (KUHP), evil acts that can be associated with conspiracy are only related to crimes regulated in Articles 104, 106, 107, and 108 of the Criminal Code (KUHP). These articles are related to crimes that are very dangerous and can threaten the safety of the state, such as treason and rebellion. In its development, evil Conspiracy does not only apply to parties who commit treason or rebellion but also applies to narcotics criminals, money laundering perpetrators, and perpetrators of corruption respectively through the laws that govern them [1].

If seen from the description above, there is an evil Conspiracy or conspiracy if the thing to commit a crime has been agreed by two or more people before, to commit a crime or in other words they have the same intention to commit this crime, whereas if it is only intention, then the act cannot be punished because the intention isn't manifested in to a concrete action. Therefore, Article 88 of the Criminal Code cannot provide the meaning of the phrase evil conspiracy in Article 15 of Law Number 31 of 1999 concerning Eradication of Corruption Crimes as amended by Law Number 20 of 2001 concerning Eradication of Criminal Acts of Corruption. This shows that if Article 88 of the Indonesian Criminal Code (KUHP) is used as a reference for interpreting Article 15 of the Corruption Crime Law, actually does not provide legal certainty because there is no meaning yet.

The problem is that when there is an agreement and refers to the elements of Article 88 of the Criminal Code, which refers to the intention to commit a crime, the agreement or the intention to commit a crime is not necessarily carried out in the form of concrete action, then there is only an evil Conspiracy. Intention that is shown by entering into a criminal conspiracy yet there is no act of execution yet means that in the case of a criminal act of corruption, a criminal Conspiracy cannot be subjected to the same criminal sanction as the perpetrator of a criminal act of corruption who has completed the criminal act as 
regulated in Article 2, Article 3, Article 5 to Article 14 of Law Number 20 of 2001 concerning Eradication of Corruption Crimes.

Another legal problem arises because of the lack of clarity of the meaning of the conspiracy itself, which causes multiple interpretations. The implementation of the meaning and substance of conspiracy in criminal acts of corruption has not been fully reflected in the laws and regulations so that both state administrators and law enforcers experience difficulties in carrying out the function of this authority.

For example, in the case of Anggodo Widjojo. In August 31, 2010, the Panel of Judges at the Corruption Court stated that Anggodo [2] was legally and convincingly proven to have committed a criminal act of corruption by imposing a sentence of 4 (four) years in prison and a fine of 150 million rupiahs, a subsidiary of 3 (three) months in prison. Chairman of the Panel of Judges Tjokorda Rai Suwamba said that only the first indictment, namely Article 15 in conjunction with Article 5 paragraph (1) letter a of Law Number 31 of 1999 concerning Eradication of Corruption in conjunction with Article 55 paragraph (1) 1 of the Criminal Code was proven, namely everyone commits an evil Conspiracy to give or promise something to a civil servant or state administrator with the intention that the civil servant or state administrator does or does not do something in his position which is contrary to fulfilled obligations.

Based on the above background, the authors are interested in further researching and analyzing the meaning of evil Conspiracy in the crime of corruption to make sure that there are no longer multiple interpretations by the means of reconstruction of the law that governs it as criminal act of corruption is an extraordinary crime that harms the state and the social community itself the following issues:

1. What are the Legal Weaknesses in the Case of Criminal Conspiracy in Corruption Crime in Indonesia Currently?

2. How is the Reconstruction of Criminal Conspiracy in Corruption Crime in Indonesia Based on Progressive Law?

\section{METHOD OF RESEARCH}

The paradigm that is used in the research this is the paradigm of constructivism which is the antithesis of the understanding that lay observation and objectivity in finding a reality or science knowledge [3]. Paradigm also looked at the science of social as an analysis of systematic against Socially Meaningful Action through observation directly and in detail to the problem analyzed.

The research type used in writing this paper is a qualitative research. Writing aims to provide a description of a society or a certain group of people or a description of a symptom or between two or more symptoms.

Approach method used in this research is Empirical-Juridical [4], which is based on the norms of law and the theory of the existing legal enforceability of a law viewpoint as interpretation.

\section{As for the source of research [5] used in this study} are

1. Primary Data, is data obtained from information and information from respondents directly obtained through interviews and literature studies.

2. Secondary Data, is an indirect source that is able to provide additional and reinforcement of research data. Sources of secondary data in the form of: Primary Legal Material and Secondary Legal Materials and Tertiary Legal Material.

In this study, the author use data collection techniques, namely literature study, interviews and documentation where the researcher is a key instrument that is the researcher himself who plans, collects, and interprets the data. Qualitative data analysis is the process of searching for, and systematically compiling data obtained from interviews, field notes and documentation by organizing data into categories, describing it into units, synthesizing, compiling into patterns, selecting important names and what will be studied and make conclusions.

\section{RESEARCH RESULT AND DISCUSSION Legal Weaknesses in the Case of Criminal Conspiracy in Corruption Crime in Indonesia Currently \\ The Constitutional Court, in relation to the} Conspiracy of Crime in the criminal act of corruption in Indonesia, provides a consideration that, all provisions in Article 2, Article 3, Article 5 to Article 14 of the Corruption Crime Law are qualitative criminal acts requiring the quality of as both a civil servant and a state officials to fulfill the elements of offenses. Therefore, the Constitutional Court is of the opinion that Article 15 in conjunction with Article 12 letter e of Law Number 31 of 1999 concerning Eradication of Corruption as amended by Law Number 20 of 2001 concerning Amendments to Law Number 31 of 1999 concerning Eradication Corruption can only be applied to an agreement between 2 (two) people or more having special qualities as civil servants or state officials as referred to in Article 1 point 1 and Article 1 point 2.

Even though it is not explicitly stated in the Constitutional Court decision, it is clear that what is meant here, for example, the case of Muhammad Riza Chalid, a Businessman who participated in a conspiracy of corruption in his meeting with the President Director of PT. Freeport Indonesia however in this case, he is a person who does not meet the special qualities as a 
Civil Servant (PNS) or state official, which means that he cannot be said to have committed an evil conspiracy.

Based on these considerations the Constitutional Court in its decision has decided, among other things, to grant the petitioner's entire petition, namely (1) the phrase "Malicious Conspiracy" in Article 15 of Law Number 31 of the Year 1999 concerning Eradication of Corruption Crime as amended by Law No. 20 of 2001 concerning Amendments to Law Number 31 of 1999 concerning Eradication of Corruption (State Gazette of the Republic of Indonesia of 2001 Number 134, Supplement to the State Gazette of the Republic of Indonesia Number 4150) contradicts the 1945 Constitution of the Republic of Indonesia as long as it is not interpreted, is that "Conspiracy is evil when two or more people who have the same quality agree to each other to commit a crime". (2) The phrase "Evil Conspiracy" in Article 15 of Law Number 31 of 1999 concerning Eradication of Corruption as amended by Law Number 20 of 2001 concerning Amendments to Law Number 31 of 1999 concerning Eradication of Corruption Crimes (State Gazette of the Republic of Indonesia of 2001 Number 134, Supplement to the State Gazette of the Republic of Indonesia Number 4150) does not have binding legal force as long as it is not interpreted, "Conspiracy is evil when two or more people who have the same quality agree to commit a crime".

In this decision the Constitutional Court has added the word "having the same quality of agreeing to commit criminal acts", namely the special quality of being a civil servant or state official as referred to in Article 1 number 1 and Article 1 point 2 of Law Number 31 of the Year 1999 concerning Eradication of The Acts of Corruption Crime as amended by Law Number 20 of 2001 concerning Amendments to Law Number 31 of 1999 concerning Eradication of Corruption Crimes.

In connection with the Constitutional Court Decision Number 21 / PUU-XIV / 2016 dated September 7, 2016, according to the author, the meaning of evil conspiracy still causes multiple interpretations, moreover the meaning of evil Conspiracy in relation to criminal acts of corruption is not included in the chapter of law. a separate criminal act of corruption, thus causing legal weakness for the perpetrators of criminal acts of corruption [6]. The Conspiracy does have several number of weaknesses related to the difficulty of the process of proof, especially with regard to elements of the agreement. The first opinion states that there must be a clear agreement between the bribe and the giver of the bribe or extortionist and the extortionist. Meanwhile, another opinion states that the agreement is not necessary.
The conception of "agreement" needs to be proven by the existence of a meeting of mind, which does not require an agreement between the bribed by the bribe or extortionist and the extortionist. However, the agreement of 2 (two) people or more to ask for something without the consent of those who are going to bribe or who will be extorted is presumably strong enough. He also emphasized that the meeting of mind does not need words that signify explicit approval, but enough with body language and sentences that indirectly indicate agreement. The rationale used is Article 55 of the Criminal Code. In addition, in criminal law theory it is known as successful silent-evil conspiracy, which means that participation in a crime, including an evil conspiracy that has been carried out secretly.

Prior to the Constitutional Court's decision, Article 15 of Law Number 31 of the Year 1999 Jo. Law Number 20 of 2001 is unable to explain the types of Conspiracy in the criminal act of corruption and does not contain elements and procedures for committing an act along with its explanation.

Furthermore, in Article 15 Law Numbers 31 of the Year 1999 Jo. Law Number 20 of 2001 states that: Anyone who tries, assists, or consults evil to commit a criminal act of corruption, shall be punished with the same penalties as referred to in Article 2, Article 3, and Article 5 to Article 14.

In Relation to this, Article 15 Law Numbers 31 of the Year 1999 Jo. Law Number 20 of 2001 relating to Article 53 and Article 56 of the Criminal Code. Article 53 of the Criminal Code also states that:

a. Attempting to commit a crime shall be punished, if the intention to do so has been found from the beginning of the execution, and the execution was not completed, it is not solely due to his own will.

b. The maximum principal penalty against crime, in case of probation, is reduced by one third.

c. If the crime is punishable by death or life imprisonment, then a maximum imprisonment of fifteen years is imposed.

d. The additional penalty for the attempted crime is the same as for crimes over.

Meanwhile, Article 56 of the Criminal Code states clearly and unequivocally that:

a. Convicted as a criminal assistant: those who deliberately helped when the crime was committed.

b. Those who deliberately provide the opportunity, means or information to commit crimes.

Meanwhile, Article 88 of the Criminal Code cannot be linked to Article 15 of the UUPTPK because Article 88 of the Criminal Code is contained in Book IX of the Criminal Code and according to Article 103 of the Criminal Code, the provisions as meant in Book IX 
of the Criminal Code cannot be linked to criminal provisions outside the Criminal Code.

Therefore, it is clear that Article 15 of the PTPK Law does not have clarity in terms of elucidation of the elements, the definition of the criminal act of Conspiracy because it differs from Article 88 of the Criminal Code. This can lead to ambiguity in law enforcement in cases of criminal Conspiracy on corruption.

In addition to that, with the Constitutional Court Decision in Case Number 25 / PUU-XIV / 2016, the phrase "can" in Article 2 and Article 3 of the Corruption Law, then the evil Conspiracy can only be proven by proving that there is an agreement between two or more people who have caused financial losses and the country's economy. If these elements are unable to be proven, then evil Conspiracy in the corruption case cannot be imposed.

So that this issue is contrary to the purpose of punishment in general. The purpose of crime cannot be separated from the flow in criminal law which is described in Absolute Theory or the theory of retaliation, that every loss, suffering experienced by a person when his legal object is injured (subjective angle) will be lost only if the perpetrator receives retribution in the form of punishment (objective angle). This is reinforced by the opinion of Immanuel Kant, one of the supporters of the absolute theory, which states that punishment is retaliation for acts against the law that are absolutely done for the sake of law and justice.

Another opinion was put forward by Stahl that punishment is a rule that originates from God's rule through state intermediaries so that the state as God's representative is obliged to maintain and implement it by avenging violations of mandatory law with punishment.

The benchmark for the practical philosophy of Indonesian national law is Pancasila, which is an abstraction of the noble values of the Indonesian people, which contain the ideals of the nation, namely a just and prosperous society both materially and spiritually, and the life of the Indonesian people as a whole [7].

So, it is clear, of course, that this is also contrary to the mandate of the One and Only Principle of Godhead where the First Principle of Pancasila calls for legal certainty and justice in fulfilling human rights and fulfilling a sense of social justice in society. So it is clear that this problem is also contrary to Article 1 paragraph (3) of the 1945 NRI Constitution and Article 28D paragraph (1) of the 1945 NRI Constitution.

\section{Reconstruction of Criminal Conspiracy in Corruption Crime in Indonesia Based on Progressive Law}

Basically, in order to create order in society, there are three things that are needed, namely justice, decency, and legal certainty. These three things, by Gustav Radbruch [8], are stated as basic legal values. The three basic values include:

First, the value of justice. In fact, the concept of justice is very difficult to find a benchmark because fairness for one party does not necessarily feel for the other party. The word justice comes from the word fair, which means that it can be accepted objectively. Furthermore, according to Aristotle, there are several definitions of justice, including equality-based, distributive, and corrective justice.

Equality-based justice is based on the principle that the law binds all people so that the justice that the law intends to achieve is understood in the context of equality. The similarities meant here consist of numerical equality and proportional equality. Numerical equality has the principle of equality of everyone before the law, while proportional equality is giving everyone what is their right.

Distributive justice is synonymous with proportional justice, where distributive justice begins with the granting of rights according to the size of the service, so that in this case justice is based on equality, but according to each portion (proportional).

Corrective justice, that is basically a justice that rests on correcting an error, for example, if there is a person's mistake that causes harm to another person, and then the person who causes the loss must provide compensation (compensation) to the party who receives the loss to restore his condition as the result of mistakes made.

Meanwhile, according to Thomas Aquinas [9], justice can be divided into two, namely justice that is general in nature and justice that is specific in nature. General Justice is justice that is formulated in statutory regulations which must be obeyed in the interests of the general public. Special justice is justice based on equality or proportionality.

Furthermore, Hans Kelsen [10] has the view that social order is just order. This view means that this system regulates human actions in ways that can bring happiness to the whole society. Justice is social happiness that humans as individuals cannot find and try to find in society. Therefore, the human longing for justice is essentially a longing for happiness. This means that there is public recognition of the resulting justice, justice that can only be obtained from the order. Furthermore, according to Socrates, as quoted by Ahmad Fadlil Sumadi [11], "the essence of law in 
giving a just decision must be: impartial, hold on to the correct facts, and not act arbitrarily on his power".

Then according to Satjipto Rahardjo as quoted by Syafruddin [12] if he said that, "justice is the essence or essence of law." which means that Justice can not only be formulated mathematically, which is called fair if someone gets the same share as others. Because there is real justice behind something that appears in these figures (metaphysical), philosophically formulated by law enforcers, namely judges.

Then, according to L.J Van Apeldoorn [13] said that, "justice should not be seen as the same meaning as equality, justice does not mean that everyone gets the same share." This means that justice requires that each case must be weighed separately; meaning that fair for one person is not necessarily fair for another. The purpose of the law is to regulate life in a peaceful way if it leads to a just rule, meaning a rule where there is a balance between the protected interests, and everyone gets as much as their share. Furthermore, L.J Van Apeldoorn also added that: "Justice should not be viewed as being equal only. Justice does not mean that everyone gets an equal share, If the law solely wants justice, so it has the sole purpose of giving each person what he deserves, then it cannot establish general rules".

A legal order that does not have general rules, written or written is impossible. The absence of general regulations means serious uncertainty, regarding what is fair and what is unfair. That uncertainty will lead to strife. Therefore, the law must define general rules, that each case must be weighed separately, the more laws meet the conditions, the more fixed rules, which eliminate uncertainty as much as possible, the more precise and sharp the rule of law, then the more pressing the justice is. According to Satjipto Rahardjo as quoted by Syafruddin, "formulating the concept of justice is how to create justice based on equilibrium values of equal rights and obligations."

Then, according to Ahmad Ali MD [14], "justice of a legal decision handed down by a judge against justice seekers must be based on substantive truth, giving something to those who are entitled to receive it."

Second, the value of certainty. According to Syafruddin Kalo, "legal certainty can be seen from two angles, namely certainty in the law itself and certainty due to the law." Furthermore, Syafruddin Kalo stated that certainty in the law means that each legal norm must be formulated with sentences in it that must not contain multi-interpretations as the result will lead to either law-abiding or non-compliance behavior. In practice, many legal events arise, where when faced with the substance of the legal norms that govern them, sometimes it is unclear or imperfect so that different interpretations arise which consequently will lead to uncertainty. Certainty in law means that each legal norm must be formulated with sentences in it that do not contain different interpretations. The result will lead to law-abiding or non-compliance behavior. In practice, many legal events arise, where when faced with the substance of the legal norms that govern them, sometimes it is unclear or imperfect so that different interpretations arise which consequently will lead to uncertainty.

Furthermore, Satjipto Rahardjo as quoted by Syafruddin Kalo said that one aspect of legal life is certainty that is the law that intends to create certainty in relationships between people in society, one that is closely related to the issue of certainty is the problem of where the law comes from. Certainty regarding the origin or source of law has become important since the law has become an increasingly formal procedure as in the field; it turns out that it can see that there are a lot of people seeking justice, especially those who have weak economies who feel they do not have legal certainty. This is because the judicial process in Indonesia is relatively long, and the costs are quite expensive, even though one of the objectives of establishing a court is to obtain legal certainty.

Therefore, what is the meaning of legal certainty is also very important for the community. Legal certainty as outlined in the judge's decision is a result based on trial facts that are legally relevant and conscientiously considered. Judges are always required to always be able to interpret the meaning of laws and other regulations that are used as the basis for their application.

This is very important, because the existence of legal certainty will greatly affect the authority of the judge and the electability of the court itself because the judge's decision which contains elements of legal certainty will contribute to the development of knowledge in the field of law due to the decision of the judge who has permanent legal force, no longer the opinion of the judge himself who decides the case, but is already the opinion of the court institution and becomes a reference for the community in their daily interactions.

Lastly, Third, the value of usefulness. According to Jeremy Bentham as quoted by Mohamad Aunurrohim [15], "the law can only be recognized as law if it provides maximum benefit to as many people as possible." For example, a judge's decision will reflect benefits, when the judge does not only apply the law textually and only pursue justice by directing it to the benefit of the interests of the parties in litigation and the interests of the community in general. This means that in applying the law, the judge should consider the final result, whether the judge's decision brings benefits or not to the parties. 
According to Satjipto Rahardjo, between the three basic legal values, there is often tension among them. This means that the three basic values have different demands because in every process of realizing these three basic values it is inseparable from the complex interests of individuals or groups in society. This problem is what caused the obstruction of law enforcement in its various dimensions.

In its development, the law between sects of one another is often even partially polemic, can be positivistic versus non-positivistic, or in other forms. This is rooted in the nature of change with all its consequences (for example, the fact that is currently happening, namely progressive law versus conservative law). With regard to law enforcement, even though legal polemics will never end as long as human life still exists, the law enforcement process must be equally important in line with judicial criticisms, especially in this discussion in the Indonesian context. Talking about law enforcement means talking about law enforcers and people who occupy strategic positions in upholding the rule of law.

The process to achieve a sense of justice is a link that must not be separated from at least the formulation of laws and regulations, the occurrence of legal cases or events, to verbal processing at the police and prosecution or lawsuits in civil cases, and then ending with a judge's verdict. obtaining permanent legal force so that the quality of the process is actually a guarantee of the quality of the culmination point of the results or benefits of a set of laws and regulations made. Thus, it is very important for the upholding of the rule of law in Indonesia as Harold J. Laksi, said that "citizens are obliged to obey certain laws only if they satisfy their sense of justice."

Based on the foregoing, in order to be able to implement regulations on the Crime of Conspiracy in Corruption in Indonesia Based on Progressive Law, it is necessary to carry out legal reconstruction on 2 articles in order to accommodate provisions that explain the meaning of conspiracy in corruption cases in Law Number 31 of the Year. 1999 Jo. Law Number 20 of the Year 2001, the two articles is Article 15A of Law Number 31 of the Year 1999 Jo. Law Number 20 of 2001, where the Conspiracy of evil as referred to in Article 15 is a crime committed by an agreement between two or more people to commit a criminal act of corruption, either openly or in secret (meeting of mind).

Second, Article 2 of Law Number 31 of the Year 1999 Jo. Law Number 20 of 2001 which is amended to:

1. Everyone who illegally commits an act of enrichment of himself or another person or a corporation that can harm the state finances or the state economy, is sentenced to imprisonment with life imprisonment or a minimum imprisonment of 4 (four) years and a maximum of 20 (twenty) years and a fine of at least Rp. 200,000,000.00 (two hundred million rupiah) and a maximum of $\mathrm{Rp}$. $1,000,000,000.00$ (one billion rupiah). And,

2. In the event that the criminal act of corruption as referred to in paragraph (1) is committed under certain circumstances, the death penalty may be imposed.

\section{CONCLUSION}

1. The implementation of law enforcement in cases of criminal conspiracy on corruption has weaknesses, among others, the unclear definition and elements of a conspiracy in Article 15 of Law Number 31 of the Year 1999 Jo. Law Number 20 of the year 2001; law enforcement that still has the paradigm that the evidence of evil conspiracy in cases of corruption is proven by real estate losses; and the culture of the influence of power and politics in enforcing the law of criminal conspiracy in corruption cases.

2. To be able to realize regulations on Criminal conspiracy in Corruption cases in Indonesia Based on Progressive Law, it is necessary to carry out legal reconstruction in 2 articles in order to accommodate provisions that explain the meaning of evil consensus in corruption cases and that is in Law Number 31 of the Year 1999 Jo. Law Number 20 of the Year 2001 and the second is the Article 15A of Law Number 31 of the Year 1999 Jo. Law Number 20 of the Year 2001, and, Article 2 Law Number 31 of the Year 1999 Jo. Law Number 20 of the year 2001 .

\section{REFERENCES}

1. Prastiwi, D. (2020). Eksistensi Pengadilan Tindak Pidana Korupsi Menurut Undangundang Nomor 46 Tahun 2009 Tentang Pengadilan Tindak Pidana Korupsi Terhadap Pemberantasan Korupsi. Pamulang Law Review. 2. 63. 10.32493/palrev.v2i1.5339.

2. BBC. (2010). Anggodo Widjojo divonis 4 tahun, Taken from https://www.bbc.com/indonesia/berita_indonesia/2 010/08/100831_anggodovonis.html, on January 2020.

3. Faisal. (2010). Menerobos Positivisme Hukum, Rangkang Education, Yogyakarta.

4. Johnny Ibrahim. (2005). Teori dan Metodologi Penelitian Hukum Normatif, Bayumedia, Surabaya.

5. Moleong, L. (2002). Metode Penelitian Kualitatif, PT Remaja Rosdakarya, Bandung.

6. Fittra, Diky. (2020). Kewenangan Komisi Pemberantasan Korupsi Dalam Kode Etik Pemberantasan Tindak Pidana Korupsi. Logika: Journal of Multidisciplinary Studies. 11. 10.25134/logika.v11i02.2870.

7. Wahyu Widodo, Sapto Budoyo and Toebagus Galang Windi Pratama. (2018). The Role of Law 
Politics on Creating Good Governance and Clean Governance for a Free-Corruption Indonesia in 2030. The Social Sciences, 13: 1307-1311.

8. Gustav, Radbruch, in Satjipto, Rahardjo. (2012). Ilmu Hukum, Citra Aditya Bakti, Bandung, 13-14.

9. Dimock, S. (2002). St. Thomas Aquinas, Law for the Common Good. Classic Readings and Canadian Cases in the Philosophy of Law, S. Dimock, ed., Prentice Hall.

10. Patterson, E. W. (1952). Hans Kelsen and His Pure Theory of Law. Calif. L. Rev., 40, 5.

11. Ahmad, F. S. (2015). Hukum dan Keadilan Sosial dalam Perspektif Hukum Ketatanegaraan, Jurnal Konstitusi, 12(4).

12. Syafruddin, K. (2015). Penegakan Hukum yang Menjamin Kepastian Hukum dan Rasa keadilan Masyarakat, taken from

https://www.academia.edu/8085012/penegakan_hu kum_yang_menjamin_kepastian_hukum_dan_rasa _keadilan_masyarakat_suatu_sumbangan_pemikira n_0_0_0_0, on 25 January 2020.

13. Hamzani, Achmad \& Hartoyo, dwijoyo \& Nuridin, \& Khasanah, Nur \& Aravik, Havis \& Yunus, Nur. (2020). Struggle for Law Principles in Law Development. Solid State Technology. 63. 18691879.

14. Ahmad, Ali, M.D. (2012). Keadilan Hukum Bagi Orang Miskin, Jurnal Mimbar Hukum dan Keadilan, Jogjakarta, 132.

15. Mohammad, A. (2015). Keadilan, Kepastian dan Kemanfaatan Hukum di Indonesia, taken from https://www.academia.edu/10691642/_Keadilan_K epastian_dan_Kemanfaatan_Hukum_di_Indonesia_, on january 2020.

16. Harold, J., Laksi, in Sabian, U. (2007). Anatomi Konflik dan Solidaritas Masyarakat Nelayan, Pustaka Pelajar, Yogyakarta, 262. 